\title{
COMPETITION, INNOVATION AND THE USE OF INNOVATIONS*
}

\author{
GEORGE SYMEONIDIS
}

I examine the effect of competition on the production and use of innovations using evidence from a natural experiment of policy reform, the introduction of cartel legislation in the UK in the late 1950s. I compare manufacturing industries which had been collusive and were therefore affected by the policy with those that had been competitive and were not affected. The intensification of competition following the abolition of cartels caused a short-run decrease in innovations produced, but had no significant effect in the long run. In contrast, innovations used increased both in the short run and in the long run.

*I thank participants at the 2017 European Meeting of the Econometric Society for valuable discussions. I am also grateful to the editor, James Roberts, and two anonymous referees for very helpful comments and suggestions.

Author's affiliation: University of Essex, Department of Economics, Wivenhoe Park, Colchester CO4 3SQ, U.K.

e-mail: symeonid@essex.ac.uk 


\section{INTRODUCTION}

The relationship between market power and innovative activity has been a muchdebated issue ever since Schumpeter's pioneering work. Large firms in concentrated markets are often seen as the main engines of technological progress, either because their ability to appropriate the returns from innovation is thought to increase their incentives to carry out $R \& D$ or because they can finance risky and costly $R \& D$ projects in the presence of financial constraints. On the other hand, it is often argued that competition strengthens the incentive to innovate by reducing inertia and managerial slack or because firms try to escape from a state of low profitability through the creation and capture of innovation rents. Both views seem intuitive; however, the empirical support for either is far from clear. One reason for the inconclusiveness of the empirical literature could be problems of methodology and interpretation. An extensive survey by Gilbert [2006] concludes that 'an ideal test of the effect of competition on innovation would be a natural experiment in which external and unforeseen events cause a discrete change in the extent of competition in an industry with no other consequences for other determinants of innovation, such as technological opportunity or appropriability'. This paper carries out such a test.

My econometric analysis of the impact of competition on the production and use of innovations uses evidence from a natural experiment that occurred in the UK in the 1960s. As a result of the introduction of the 1956 Restrictive Trade Practices Act, collusive agreements among firms, covering a wide range of manufacturing industries, were cancelled. This caused an intensification of price competition in many industries during the 1960s. These can be compared to a control group of industries which did not have agreements significantly restricting competition and were not affected by the legislation. A comparison of the two groups of industries over a 25-year period, using 
data both before and after the implementation of the 1956 Act, can provide important insights on the links between competition and innovation.

The introduction of cartel law in the UK provides us with a way to by-pass two difficult problems that have been endemic in empirical studies of the effects of competition. The first problem is how to measure the intensity of competition. The second is how to unravel the complex links between competition and other variables, given that these may simultaneously affect one another or be jointly influenced by other factors, thus making the identification of causal effects very difficult. The present setup allows us to by-pass these difficulties because a change in the intensity of competition across a wide range of industries was induced by an exogenous and measurable institutional change. An analysis of the effects of competition can therefore be carried out by distinguishing between industries that were affected by the shift in cartel policy and industries that were competitive throughout the period examined. Moreover, the inter-temporal structure of the data and the exogeneity of the institutional change allow us to address any concerns about potential biases in the estimated impact of competition caused by the existence of complex links between competition and other variables.

The empirical literature on competition and innovation has provided mixed results. Thus Scherer and Huh [1992] report evidence of US firms reducing, on average, their R\&D intensity in the short run in response to intensified foreign competition, although this negative effect does not seem to persist in the longer term. A study of early $20^{\text {th }}$ century US industry (Nicholas [2003]) supports the Schumpeterian view of market power promoting innovation. On the other hand, Geroski [1990] and Blundell et al. [1995, 1999] have found evidence of a positive link between competition and innovation in British industry, although Blundell et al. have also found that large firms innovate more. A number of other studies, going back to Scherer [1967] and including 
the influential work of Aghion et al. [2005], have found an inverted U relationship between the two variables - but see Correa [2012] and Hashmi [2013] for alternative interpretations. Some recent work reports evidence of a positive competition effect on innovation in firms or industries that are close to the technology frontier and a negative or no effect for other firms or industries (Aghion et al. [2009], Gorodnichenko et al. [2010], Amiti and Khandelwal [2013]). Broadberry and Crafts [2001], in a study which is related to my own work, have found no evidence of an association between innovation and the incidence of collusion in 1950s Britain. A limitation of their study derives from the use of cross-section data, which makes it difficult to draw any conclusions on causality from their results. ${ }^{1}$ Finally, although most studies of the effect of competition-enhancing reforms or trade liberalisation on innovation have found a positive effect (for instance, Griffith et al. [2010], Bloom et al. [2016]), some (such as Autor et al. [2016]) have found a negative one. All in all, a clear link of any kind between competition and innovation has proved difficult to establish in general, and has only been confirmed for particular countries, time periods or classes of industries. Several surveys of the empirical literature (Cohen [1995], Symeonidis [1997], Gilbert [2006]) have therefore concluded that there may be no general relationship between market power and innovation and that industry characteristics such as appropriability conditions, demand and especially technological opportunity explain much more of the cross-industry variation in innovative activity than market power or market structure.

In addition to presenting evidence from a unique natural experiment, the present research explores an important distinction between production and use of innovations. This has seldom been addressed explicitly in connection with competition, as most of the literature has focused either on overall R\&D expenditure or on what is regarded as the main output of R\&D, namely innovations produced or patents. ${ }^{2}$ However, studies of 
the absorption role of $R \& D$ have emphasised how $R \& D$ expenditure also allows firms to better assimilate technological innovations by others and that the effect of this can be large in practice (Cohen and Levinthal [1989], Griffith et al. [2004]). Furthermore, the use of an innovation commonly requires an active involvement in the innovation process. In fact, users, as opposed to manufacturers conducting their own $R \& D$, are a major source of innovations in several industries (Von Hippel [1988]). In a survey of about 6000 US innovating firms (Arora et al. [2016]), the most important recent innovation for about half of the firms had originated from an outside source, most frequently customers. The propensity to be a user is therefore likely to be influenced by industry characteristics, including competition. However, few studies have examined how competition affects the use, as opposed to the production, of innovations - an exception is Geroski [1990] for 1970s Britain - and there are hardly any comparisons of the two in the same context and using the same data sources. This may be a worthwhile exercise, if only because the use of innovations will directly impact on productivity, and the evidence in favour of a positive competition-productivity link seems stronger than the evidence for a positive association between competition and innovation.

Why might competition affect innovation production and use differently? One answer to this question goes back to some of the standard theoretical arguments in the literature inspired by Schumpeter's work. To the extent that competition reduces profitability, firms facing more intense competition may need to cut down on costly $R \& D$ projects if they are financially constrained, at least in the short run. In the longer term, R\&D intensity and the production of innovations may be mainly driven by supply-side factors like technological opportunity and not be very responsive to competition. On the other hand, financial constraints should not hinder a firm's ability to restore profitability and/or avoid exit through strategies that aim to reduce cost and 
enhance productivity, including the use of new technologies made available by other firms or industries. One might therefore expect firms to attempt to escape tougher competition through an increase in the use of innovations.

To the best of my knowledge, this paper is the first that exploits a natural experiment of policy reform to analyse the impact of competition on the production as well as the use of innovations. It extends significantly my earlier work on the effect of the 1956 cartel law on innovations produced (Symeonidis [2007, 2002]), which found that there was no significant effect in the long run. I now consider both innovations produced and innovations used, I compare long-run to short-run effects, and I test for heterogeneous effects of competition across classes of industries. I find that the intensification of competition following the abolition of cartels had a negative shortrun effect on innovations produced, but no significant long-run effect. In contrast, competition caused an increase in innovations used both in the short run and in the long run. Although I do not explore here the links between innovation and other endogenous variables, my results are consistent with the evidence reported in Swann et al. [1973, 1974] and Symeonidis [2008, 2002] on the evolution of profitability and productivity after the abolition of the British cartels. In particular, the short-run decline and subsequent recovery of innovations produced is in line with the temporary fall and subsequent recovery of profitability, whereas the increase in the use of innovations is consistent with the higher productivity growth experienced by previously collusive British industries.

\section{COMPETITION IN BRITISH MANUFACTURING INDUSTRY}

Explicit restrictive agreements among firms were widespread in British industry in the mid-1950s: nearly half of manufacturing industry was subject to price-fixing. Although 
the agreements were not enforceable at law, they were not illegal. Most of them specified minimum or fixed producer prices. There were generally no restrictions on longer-term decisions such as investment in capacity, advertising or R\&D expenditure. A description of the institutional changes and the evolution of competition from the 1950s to the early 1970s and a detailed survey of restrictive agreements across all British manufacturing industries can be found in Symeonidis [2002]. Here I summarise the evidence and I describe the construction of the competition data for this paper.

The 1956 Restrictive Trade Practices Act required the registration of restrictive agreements, including verbal or even implied arrangements, on goods. Registered agreements should be abandoned, unless they were either successfully defended by the parties in the newly created Restrictive Practices Court as producing benefits that offset the presumed damage or cleared by the Registrar of Restrictive Trading Agreements as not significantly affecting competition. Since the attitude of the Court could not be known until the first cases had been heard, the large majority of industries registered their agreements rather than abandoning or secretly continuing them (Swann et al. [1974]). The first agreements came before the Court in 1959 and were struck down. This caused most industries to voluntarily drop their agreements rather than incur the costs of a Court case with little hope of success.

Were the agreements effective? This depended on two factors: the extent to which the parties themselves conformed to them and the extent of competition from outside firms, domestic or foreign. Evidence from the registered agreements, several industry reports published by the Monopolies and Restrictive Practices Commission during the 1950s, the Political and Economic Planning [1957] survey of industrial trade associations and a large number of case studies discussed in Swann et al. [1973, 1974] suggests that in most industries the agreements had been operated 
effectively, the parties typically accounted for a large fraction of the market and contained the largest and best-known domestic firms, and outside competition was usually weak. For instance, Swann et al. report cartel market shares of $90 \%$ or higher in about two thirds of the 40 industries they examine, and $75 \%$ or higher in all but two cases. Competition from imports was often limited as a result of tariffs and quantitative controls, differing technical standards, transport costs or international restrictive agreements. Finally, the legality of the agreements and the institutional role of the trade associations that operated them had facilitated the coordination, monitoring and enforcement of collusion by the cartels.

To what extent did collusion break down following the abolition of cartels? Evidence from Heath [1961, 1963], Swann et al. [1973, 1974] and the annual reports of the Registrar of Restrictive Trading Agreements indicates that price competition intensified in the short run in many industries. However, in many others, agreements to exchange information on prices or price changes replaced the former explicit collusive arrangements, and competition emerged only after these information agreements were abandoned in the mid-1960s, after some of them were struck down by the Restrictive Practices Court. Price wars occurred in a number of previously collusive industries in the second half of the 1960s, and the final blow came with the provisions of the 1968 Restrictive Trade Practices Act regarding information agreements. Thus in many cases competition emerged more than a decade after the introduction of the 1956 legislation. Overall, sooner or later the large majority of industries with restrictive agreements in the 1950s did experience a breakdown of collusion as a result of the 1956 Act.

My main source of data on competition are the agreements registered under the 1956 Act. In addition, I use various other sources to identify unregistered agreements, including the industry reports of the Monopolies Commission, the 1955 Monopolies 
Commission report on collective discrimination, the 1949 report of the Lloyds' Committee on resale price maintenance, industry studies contained in Burn [1958] and Hart et al. [1973], the Board of Trade annual reports from 1950 to 1956, and the Political and Economic Planning [1957] survey of trade associations (including unpublished background material for this survey). The use of a diverse range of sources implies that any measurement error caused by ineffective agreements or unknown cases of collusion in the data should be small.

My approach to modelling the competition effect is based on distinguishing between industries with a change of competition regime following the 1956 Act and those without a change in regime. All manufacturing industries were classified as collusive, competitive or ambiguous according to their state of competition in the 1950s on the basis of three criteria: the reliability of the data source; the types of restrictions; and the proportion of an industry's total sales revenue covered by products subject to agreements and, for each product, the fraction of the UK market covered by cartel firms. In particular, the various types of restrictions were classified as significant, not significant or uncertain, according to their likely impact on competition. An industry was classified as collusive in the 1950s if the products subject to significant restrictions accounted for more than $50 \%$ of total industry sales. It was classified as competitive if the products subject to significant or uncertain restrictions accounted for less than $20 \%$ of industry sales. And it was classified as ambiguous in all remaining cases. I have used the $50 \%$ cut-off point because in some cases most core industry products were subject to price-fixing although some were not, and one would expect a significant impact of the 1956 Act in such cases. I have used the 20\% cut-off point because in some cases secondary industry products were subject to restrictive agreements, although core 
products were not. Variations in these cut-off points (for instance, using $70 \%$ instead of $50 \%$, or $10 \%$ instead of $20 \%$ ) do not significantly affect the results. ${ }^{3}$

A binary variable, CHANGE, was then defined, which takes the value 1 for industries with a change of competition regime and 0 otherwise. Industries classified as ambiguous will also be used to check the robustness of my results. ${ }^{4}$ There are five years in the data set: 1954, 1958, 1963, 1968 and 1973. The first four of these are the only ones in the 1950s and 1960s for which comparable Census of Production data are available, and 1973 is the last year before the oil crisis. Note that although the cartel law was introduced in 1956, it was not until 1959 that collusive industries started cancelling their agreements. And as competition was often slow to emerge, the law had a significant impact well into the late 1960s and even early 1970s.

\section{ENDOGENOUS VARIABLES AND DESCRIPTIVE STATISTICS}

The econometric analysis in this paper is based on a comparison of industries affected by the 1956 Act with a control group of industries not affected. I will use two different samples. The first consists of 72 manufacturing industries which have been consistent producers of innovations, including 17 with a change of competition regime, 26 competitive and 29 ambiguous. The level of aggregation for the industries of this sample is usually the three-digit level, although I was often able to make use of more disaggregated industry categories at the four-digit level. The second sample consists of 89 three-digit manufacturing industries which have been consistent users of innovations, including 26 with a change of competition regime, 33 competitive and 30 ambiguous. ${ }^{5}$ The reasons for using separate samples are, first, that more industries are users than producers of innovations and, second, that innovations produced could often be assigned to more disaggregated industry categories than innovations used. 
Following Geroski [1990], Blundell et al. [1995, 1999] and others, my measure of innovative activity is innovation counts and the data cover all significant innovations introduced in the UK during the period under study, as evaluated by industry experts. Innovation counts, when carefully constructed, as in the present case, have several advantages. They are not subject to under-reporting, as is sometimes the case with R\&D expenditure. They are a more accurate record of innovative output than patents, whose value and use across industries varies widely, and they allow for a distinction between innovation production and use. Finally, as pointed out by Geroski [1994], it is ultimately innovations, not R\&D or patents, that impact on markets and welfare.

The innovations data come from the SPRU survey of 4378 significant innovations commercialised by British firms during 1945-1983 (see Townsend et al. [1981], Robson et al. [1988] and Geroski [1994] for extensive discussions of these data). About $70 \%$ of these are product innovations, and the rest are process innovations. The data was collected in three waves over a period of fifteen years by contacting a group of about 400 experts who had detailed knowledge of their own sectors of British industry. In addition to a brief description of each innovation, the database reports the principal three-digit industry classification of the innovating firm, the industry classification of the innovation and the industry classification of the first user of the innovation. The last of these was my main information for the use of innovations. For the production of innovations, none of the first two entries is entirely satisfactory: the principal industry classification of the innovating firm may be misleading in the case of diversified firms, which are numerous in this data set, whereas the industry classification of the innovation is misleading in the case of process innovations. I have therefore reclassified the innovations in the database, so that product innovations are classified according to the industry of the innovation, whereas process innovations are 
classified according to the industry in whose production process the innovation was made. $^{6}$

For a small number of entries in the SPRU database (about $10 \%$ of the total), a first-user sector is reported rather than an industry within the sector. I have therefore constructed my variable for innovations used in two different ways. The first approach was to exclude these ambiguous entries from my sample of innovations used - this gives a slight underestimate of innovations used in some industries and also reduces sample size by eliminating some low-innovation industries. The second approach was to assign each of these entries $x$ times, once to each individual industry, in a sector with $\mathrm{x}$ industries - this gives an overestimate. Results will be presented for both definitions.

Although the SPRU data record the number of innovations in every year, it is necessary to group the innovation counts into five-year periods so that they can be matched with data on sales revenue and other variables, which are available at roughly five-year intervals during the 1950s and 1960s. It seems reasonable to assume that sales revenue, say, in any year $\mathrm{t}$ is a reliable measure of average market size between $\mathrm{t}-2$ and $t+2$, and can therefore be treated as a relevant determinant of $R \& D$ expenditure between $t-2$ and $t+2$. Estimates of the average time lag between the beginning of a research project and the commercialisation of research output across industries range from one to four years (Mansfield et al. [1971], Pakes and Schankerman [1984], Acs and Audretsch [1988]). One way of linking R\&D spending with innovation counts often used in the literature is to assume a one-year lag between the bulk of $R \& D$ expenditure and the commercialisation of the resulting innovation. On the assumption of a one-year lag, sales revenue in year $\mathrm{t}$ should be matched with the number of innovations commercialised between $\mathrm{t}-1$ and $\mathrm{t}+3 .^{7}$ The time periods chosen here for grouping the innovation counts are therefore 1952-56, 1957-61, 1962-66, 1967-71 and 1972-76. ${ }^{8}$ 
These were matched with data on sales revenue and other variables for 1953, 1958, 1963, 1968 and 1973, respectively.

The above discussion refers to the production of innovations, but a similar argument can be made about their use: there is a time lag between the recognition of a need of a user industry and the commercialisation of the innovation that responds to that need. The notion that research activity by firms occurs to a large extent as a response to needs of users is important for interpreting my results on innovations used. I essentially maintain that firms in user industries do not passively adopt innovations but are more or less actively involved - and so the propensity to be a user is influenced by industry characteristics, including competition. This is obvious for process innovations, where the producer is also the user. According to the influential demand-pull theory of innovation (Schmookler [1966]), it is largely true for product innovations as well. In fact, users, as opposed to manufacturers conducting in-house $R \& D$, are a major source of innovations in several industries (Von Hippel [1988], Arora et al [2016]). I should also emphasise that the SPRU data assign each innovation to a single first-user industry rather than to a set of user industries. This strengthens my view of users as having an active role not only in process but also in product innovations - at the very least by liaising with and communicating their needs and evaluations to innovating firms, and often by contributing significantly to the innovation process.

\section{Place Table I approximately here \\ Place Table II approximately here}

Table I presents descriptive statistics for innovations produced over a period of 25 years, distinguishing between industries with a change of competition regime and 
those not affected by the 1956 cartel law. Statistics on innovations used, excluding those assigned to entire sectors, are presented in Table II. Two things stand out in both tables. First, total innovation counts increased sharply between the 1950s and the early 1960s, continued to rise slowly during the 1960s and fell in the 1970s. The trend is inevitably the same for innovations produced and used, and the minor differences across the two tables are due to differences in industry definitions in the two data sets. This trend must reflect the overall evolution of demand and industrial output during the period up to and including the 1973-1975 recession. Second, there is a clear difference between the two groups, with industries subject to a change of competition regime being far less innovative, although not considerably less likely to use innovations, than competitive industries throughout the period. I will return to this point when presenting the econometric model and results below, and I will provide an interpretation in terms of intrinsic differences in technological opportunity across industries.

The descriptive statistics also reveal differences between the two groups in the way innovation evolved over time. Table I indicates a decline in innovations produced in previously collusive industries relative to the control group, especially during the 1960s: the average number fell from 2.9 to 2.1 in industries with $C H A N G E=1$, whereas it increased from 4.2 to 6.5 in the group with $C H A N G E=0$. Crucially, this was not a continuation of a 1950s trend, since innovation counts had been increasing in both groups between the mid- and the late 1950s. On the other hand, Table II shows a relative increase in the use of innovations in previously collusive industries during the 1960s: the average number went up from 3.3 to 4.0 , whereas it fell from 4.5 to 4.3 in competitive industries. Once again this is not due to pre-existing trend differentials, since the increase had actually been larger in competitive industries during the 1950s. It seems clear that any association between CHANGE and the evolution of innovations 
used or produced after 1957 is not driven by pre-existing diverging trends across industries. This will be confirmed by the econometric results below.

Thus although there was a relative increase in the use of innovations in previously collusive industries in the 1960s, it seems that a relatively smaller number of these innovations were produced in industries that had been affected by cartel policy. All in all, the contrast between the two groups of industries as well as between production and use of innovations within the previously collusive group is striking. I will now explore this evidence further using econometric analysis.

\section{ECONOMETRIC EVIDENCE 1: COMPETITION AND THE PRODUCTION OF INNOVATIONS}

The specifications used in this paper are panel data models with individual-specific (industry) effects. This allows me to control for industry characteristics important for innovation that are relatively stable over time - such as the degree of spillovers, which affects the appropriability of innovation rents and thus the incentives to carry out R\&D, and, most importantly, technological opportunity. The ranking of manufacturing sectors according to R\&D intensity tends to be very similar across countries and time periods, which is consistent with technological opportunity at the sector level being stable over a period of 25 years. This may be less obvious at the industry level, but any changes in technological opportunity over time will not bias my results to the extent that they are not correlated with the variable CHANGE or other explanatory variables.

My approach is based on the difference-in-differences methodology, which consists in comparing the difference between the average change in the variable of interest in the treatment group and the average change in the same variable in the control group. Year dummies will be included to control for other factors that may 
have influenced innovation over the period under study, such as government policy towards $R \& D$, the progressive opening of the British economy, and macroeconomic fluctuations. It seems plausible to assume that these factors would have affected more or less equally the previously collusive and the competitive industries. With respect to foreign competition in particular, there is no evidence that any changes during the 1960s were different in the two groups. Kitchin [1976] provides estimates of effective tariff protection for 1963 and 1968 at a level of aggregation between the twodigit and the three-digit. Effective protection increased, according to these estimates, in 6 out of 12 industries or sectors that were mostly collusive in the 1950s and decreased in the other 6. For industries or sectors that were mostly competitive, the respective numbers were 8 and 10. Tariff protection changes before 1963 were much smaller. Thus the estimated effect of the breakdown of cartels in my regressions is unlikely to be biased because of the lack of a better control for the extent of foreign competition.

The dependent variable, the number of innovations produced in any given industry and time period, is a count (a non-negative integer). Three important features of the data generating process for innovations have directed my choice of econometric model. First, there is considerable overdispersion in the dependent variable, as can be seen from the means and standard deviations in Table I. In such circumstances, the standard Poisson model for count data is not appropriate (Cameron and Trivedi [1998], Hausman et al. [1984]). On the other hand, a negative binomial model can provide valid results under overdispersion. Second, there is no significant excess zero problem in the present data. Not only is the number of zeros relatively small, but also these always occur in some time period for industries that do produce innovations at other times. In other words, the exclusion of consistent non-producers of innovations from the sample implies that the zeros are part of the same process that generates the non-zeros. Thus the 
use of a zero-inflated model is neither necessary nor recommended. Third, as already mentioned, collusive industries had, on average, a much lower average number of innovations throughout the period than competitive ones. This implies that CHANGE is correlated with the industry-specific effects, so a random-effects model is not applicable. To obtain consistent estimates, the conditional fixed-effects negative binomial specification proposed in Hausman et al. [1984] will therefore be used.

My benchmark econometric model for the production of innovations is

$$
\begin{aligned}
& \mathrm{E}\left[I_{\left.N N O V_{i t}\right]}\right]=\exp \left(\alpha_{i}+\beta_{1} \ln S A L E S_{i t}+\beta_{2} Y 53+\beta_{3} Y 63+\beta_{4} Y 68+\beta_{5} Y 73+\right. \\
& \beta_{6} R D 2 \times Y 53+\beta_{7} R D 2 \times Y 63+\beta_{8} R D 2 \times Y 68+\beta_{9} R D 2 \times Y 73+ \\
& \left.\beta_{10} C H A N G E \times Y 53+\beta_{11} C H A N G E \times Y 63+\beta_{12} C H A N G E \times Y 68+\beta_{13} C H A N G E \times Y 73\right) .
\end{aligned}
$$

INNOV is the number of innovations produced by British firms in any given industry and time period. SALES is total sales revenue of UK firms deflated by an industryspecific producer price index, and serves as a measure of market size, an important determinant of R\&D expenditure in standard models. ${ }^{9}$ Given the assumed one-year innovation lag, reverse causality is unlikely. In any case, a simple check that I will perform below to ensure that there is no significant bias in the coefficients of interest is to run regressions without $\ln S A L E S$ and confirm that the results remain essentially unchanged. $Y 53, Y 63, Y 68$ and $Y 73$ are time dummies corresponding to the first and the last three time periods in the panel. The baseline period is 1956-60, essentially the last few years of widespread cartelisation: since in most collusive industries price-fixing continued until the early or mid-1960s, the period 1956-60 was a time when competition had not yet emerged to any significant scale. This seemed a much better choice of baseline period than 1951-55, for at least two reasons. ${ }^{10}$ First, it helps to bring sharply into focus the short-run effect of the breakdown of cartels on innovation. Second, although most British cartels were long-standing, the 
registration of agreements occurred after 1956, so any measurement error in the variable CHANGE should be lower for 1956-60 than for the earlier period. ${ }^{11}$

The interaction terms with $R D 2$ are included to capture any differences in the evolution of innovation over time between R\&D-intensive industries and low-R\&D industries: $R D 2=1$ for industries with typical $\mathrm{R} \& \mathrm{D}$-sales ratio throughout the period higher than $2 \%$ and 0 otherwise. The $2 \% \mathrm{R} \& \mathrm{D}$-sales ratio was chosen as a cut-off point that may provide a more meaningful split of the industries in this sample, all of which are consistent producers of significant innovations, than the $1 \% \mathrm{R} \& \mathrm{D}$-sales ratio. ${ }^{12}$ In any case, an alternative variable, $R D 12$, will also be used. $R D 12$ takes the values 0 for industries with typical R\&D-sales ratio below $1 \%, 1$ for industries with $\mathrm{R} \& \mathrm{D}$-sales ratio between $1 \%$ and $2 \%$, and 2 for industries with R\&D-sales ratio higher than $2 \%$.

The interactions of the time dummies with CHANGE should pick up any differences in the evolution of innovation between industries with a change of competition regime $(C H A N G E=1)$ and industries without such a change $(C H A N G E=$ 0 ). Thus the coefficients on $C H A N G E \times Y 63$ and $C H A N G E \times Y 68$ measure the effect of the cartel law on innovations produced during 1962-66 and 1967-71, respectively. Given the slow rate of emergence of competition and the time lag between the launch of an $R \& D$ project and the commercialisation of the resulting innovations, I regard this as the short-run effect of competition. The coefficient on CHANGE $\times Y 73$ measures the long-run effect. My approach is analogous to allowing for group-specific time effects such that any impact of the cartel law is represented by divergent trends in the treatment and the control group after 1960. Note that these coefficients or any others in my model are not meant to say anything about the level of innovation. My approach relies on comparing the evolution of innovations produced across the two groups of industries. 
Two other variables will be included in some specifications. In particular, $\ln K / L$, the logarithm of the capital-labour ratio, is a proxy for setup costs or economies of scale. UNION, a measure of union density defined as the number of unionised employees over the total number of employees, is included because it is sometimes argued that union power may hinder innovation. ${ }^{13}$ All the variables are defined at the industry level. Note that my model does not include a measure of market structure among the regressors: it is a reduced-form model of the effects of policy reform derived from a theoretical framework where market structure and innovation are both seen as endogenous. ${ }^{14}$ Data sources include the Census of Production (various years), O’Mahony and Oulton [1990] for capital stock, Bain and Price [1980] for union density, and various official and market research sources for R\&D. Details are provided in the Data Appendix, where I also describe how I constructed 1953 estimates for certain variables using the published 1954 and 1958 data.

The identifying assumption is that any difference in the evolution of innovative activity between industries with CHANGE $=1$ and industries with CHANGE $=0$ during the 1960s and 1970s is not due to unobserved characteristics that differ between the two groups of industries. Although the initial conditions were different in the two groups, with the average number of innovations produced in 1957-61 being far larger in competitive industries than in collusive ones, this was also the case in the previous period, 1952-56, and the two groups appear to have been on a common time trend before the breakdown of cartels - as will be confirmed by the econometric results below. Therefore any estimated difference in the evolution of innovations in later periods is likely to be due to the 1956 law, not to any diverging prior trends. Alternatively, if there is no difference in the respective trends in later periods, we may conclude that the abolition of cartels had no effect on innovation. Furthermore, the 
difference in levels between the two groups remains large in all later periods. This suggests that cartelisation in the 1950s is correlated with a variable that influences innovative activity and is relatively stable over time. An obvious candidate is technological opportunity, which is captured in the present model by the industry effects. Any correlation between the industry effects and the endogenous variable will not bias the econometric coefficients in fixed effects specifications.

Table III contains results from regressions for INNOV using a conditional fixedeffects negative binomial model. Column (1) presents my benchmark specification and column (2) contains additional regressors. These regressions also provide a formal test of the parallel trends assumption underlying the difference-in-differences approach: the coefficient on CHANGE $\times$ Y53 captures any difference in the evolution of the dependent variable between the first pre-treatment period and the last pre-treatment (and baseline) period across the two groups of industries, controlling for other relevant explanatory variables. Since the coefficient on $C H A N G E \times Y 53$ is not statistically significant, we can conclude that there is no evidence of different trends in previously collusive and competitive industries before the breakdown of the cartels. ${ }^{15}$ In specification (3) the year dummy and interaction terms for 1953 (none of which is statistically significant) are omitted, thus effectively treating the 1950s as a single baseline period. Although this may blur any short-run effect of the abolition of cartels, it also glosses over any fluctuations in INNOV during the 1950s, which are unlikely to be related to collusion or its breakdown, and thus provides a robustness check for the long-run effect of competition. Industries with ambiguous state of competition in the 1950s are excluded in all three specifications.

Place Table III approximately here 
There is no evidence from columns (1)-(3) of any significant long-run effect of the intensification of price competition following the 1956 cartel law on innovations produced in British industry: the coefficient on $C H A N G E \times Y 73$ is nowhere statistically significant, even at the $20 \%$ level. On the other hand, there is evidence of a negative short-run effect: the coefficient on CHANGE $\times Y 68$ is negative and always statistically significant at the $5 \%$ or $10 \%$ level. In specifications not shown, I have replaced $R D 2$ with $R D 12$ but the results did not change. The estimated short-run effect of competition is large. For instance, the coefficient on CHANGE $\times$ Y68 in column (2) indicates a fall in the logarithm of expected innovation counts of -0.65 between the baseline period and 1967-71 in industries with a change of competition regime. This corresponds to a reduction in the number of innovations of around 45\%. To put this percentage change into perspective, recall from Table I that the average number of innovations produced per industry and time period is very low. The sum of the coefficients on Y68 and CHANGE $\times$ Y68 suggests a $30 \%$ fall of INNOV in previously collusive industries during the 1960s. This is very close to what is shown in Table I, where the average value of INNOV in previously collusive industries falls from 2.9 to 2.1 during that period.

Apart from the evidence of a temporary fall in innovative activity in previously collusive industries and the time effects, most other variables have little explanatory power. An exception is union density, which seems to reduce innovation. Union density in British manufacturing industries was stable for much of the period under study, but increased significantly in the late 1960 s and early 1970 s from about $45 \%$ to $55 \%$ on average. The coefficient on UNION might therefore be best interpreted as evidence that the 1970s fall in innovation shown in Table I was more pronounced in industries with large increases in unionisation. The coefficients on the interactions of $R D 2$ with the 
time dummies (not shown) are occasionally statistically significant at the $10 \%$ level. Any impact of market size on innovative activity is obscured by the time effects, which suggest a large increase in innovation counts in the early 1960s followed by a relative stability in later periods and a fall in the 1970s, consistent with Table I. These results suggest that changes in innovative output in British industries over the period under study were driven to a considerable extent by unobserved characteristics and random events. This is not surprising, given the uncertainty involved in the research process and the fact that the SPRU database records significant, not incremental, innovations.

In columns (4)-(6) of Table III I consider heterogeneous effects of competition, motivated by the recent literature on the relevance of an industry's distance to the world technological frontier for the competition-innovation relationship. An important distinction in the present context is between $R \& D$-intensive and low-R\&D industries. I add the three-way interaction terms $R D 12 \times C H A N G E \times Y 58, R D 12 \times C H A N G E \times Y 63$, $R D 12 \times C H A N G E \times Y 68$ and $R D 12 \times C H A N G E \times Y 73$, and I also replace $R D 2$ with $R D 12$ elsewhere in the model. In these regressions the coefficients on the three-way interactions test whether the general results on the effect of competition on innovations produced are different across industries depending on their research intensity. I use $R D 12$ instead of $R D 2$ to allow for a finer distinction between medium-R\&D and high$R \& D$ industries, with the former being given less weight than the latter in assessing the role of R\&D intensity for the competition-innovation relationship. Column (4) presents the benchmark model and column (5) includes additional regressors. Then in specification (6) I replace CHANGE with CHANGE2, which is equal to 1 for industries with a change of competition regime, 0 for competitive ones and 0.5 for industries with ambiguous state of competition in the 1950s. Although the construction of CHANGE2 is somewhat ad hoc and these results should be interpreted with caution, the 
motivation for this last specification is that any heterogeneous effects of competition might be easier to identify in the larger sample of 72 industries.

The results suggest that $R \& D$ intensity is not a factor in the relationship between competition and innovation in these data: the coefficients on the three-way interactions are not statistically significant. On the other hand, the coefficient on CHANGE $\times Y 68$ is always negative, larger than the same coefficient in regressions without the three-way interactions, and statistically significant at the $5 \%$ level in every specification. Once again this is only a short-run effect - there is no evidence of long-run persistence.

I performed several additional robustness checks. These included: 1) applying slightly different criteria to classify the industries as collusive or competitive, as discussed in section II; 2) constructing INNOV on the assumption of a two-year rather than a one-year innovation lag; 3) using a general producer price index instead of industry-specific price indices as deflator for sales revenue, or dropping $\ln S A L E S$ altogether; 4) controlling for unionisation using an alternative set of variables (see the next section) and 5) adding further control variables - the number of firms, average plant size (another proxy for setup costs or economies of scale) and the sales growth rate - all of which were not statistically significant. The evidence for a temporary decline and lack of any significant long-run change in innovation following the breakdown of cartels was confirmed in all specifications.

\section{ECONOMETRIC EVIDENCE 2: COMPETITION AND THE USE OF INNOVATIONS}

I now turn to the econometric analysis of the effect of cartel policy on the number of significant innovations used across industries. I estimate again a reduced-form model using a difference-in-differences methodology. All my specifications include year 
dummies in addition to the industry effects and other control variables. The dependent variable is once again a count variable which is subject to considerable overdispersion, as evidenced in Table II, but does not contain a large number of zeros. Furthermore, the competition measure CHANGE may be correlated with the industry effects. These features point again to a conditional fixed-effects negative binomial model.

My basic specification is

$$
\begin{aligned}
& \mathrm{E}\left[\mathrm{INNUSED}_{i t}\right]=\exp \left(\alpha_{i}+\beta_{1} \ln S A L E S_{i t}+\beta_{2} Y 53+\beta_{3} Y 63+\beta_{4} Y 68+\beta_{5} Y 73+\right. \\
& \beta_{6} R D 2 \times Y 53+\beta_{7} R D 2 \times Y 63+\beta_{8} R D 2 \times Y 68+\beta_{9} R D 2 \times Y 73+ \\
& \beta_{10} A G R E E \times Y 53+\beta_{11} A G R E E \times Y 63+\beta_{12} A G R E E \times Y 68+\beta_{13} A G R E E \times Y 73+ \\
& \left.\beta_{14} C H A N G E \times Y 53+\beta_{15} C H A N G E \times Y 63+\beta_{16} C H A N G E \times Y 68+\beta_{17} C H A N G E \times Y 73\right) .
\end{aligned}
$$

The dependent variable is the number of innovations for which an industry was the first user in any given period, defined in two different ways, as discussed in section III. For INNUSED1, I discarded all innovations assigned to an entire user sector in the SPRU database. For INNUSED2, I treated all the industries in the sectors in question as multiple first users of these innovations. The explanatory variables are as previously defined and the remarks made in the previous section on the general form of the model and the control variables apply here as well and will not be repeated. The coefficients of main interest are again those on the interaction terms with CHANGE.

Decisions by firms on the use of technology which may bring about changes in the production process have much stronger implications for employees than decisions on R\&D expenditure, and may be subject to bargaining with unions. AGREE is the percentage of employees in any industry covered by collective bargaining agreements (whether national, local or firm-level) in 1973. The 1960s and 1970s were a time of strong and increasing union power in British industry. Any effect of unionisation on changes over time in the use of innovations should be captured by the interaction terms AGREE $\times Y 53, A G R E E \times 63, A G R E E \times Y 68$ and AGREE $\times Y 73 .{ }^{16}$ AGREE and CHANGE 
are strongly correlated, with a correlation coefficient of 0.35 . In some specifications I also include $\ln P L A N T S I Z E$, the logarithm of industry employment divided by the number of plants, or average plant size, a proxy for setup costs or economies of scale.

Once again the identifying assumption is that any difference in the evolution of INNUSED between industries with CHANGE $=1$ and industries with CHANGE $=0$ during the 1960s and 1970s is not due to unobserved characteristics that differ between the two groups of industries. This seems plausible. The difference in initial conditions was not large, as shown in Table II, and both groups of industries experienced an increase in innovation use before the breakdown of cartels. This was somewhat more pronounced in competitive industries, but the difference is not significant - as will be confirmed by the econometric results below. Furthermore, even if CHANGE is influenced by omitted variables that are correlated with INNUSED, these variables are more likely to be part of the industry-specific effect than of the error term, since the large majority of restrictive agreements were in operation for many years before the introduction of the 1956 law. Any such correlations, if they exist, will not bias the econometric coefficients in fixed effects specifications.

Table IV reports results from a conditional fixed-effects negative binomial model. Column (1) presents my basic specification, with INNUSED1 as dependent variable. In column (2) additional regressors are included. In specification (3) CHANGE is replaced by CHANGE2, as previously defined. This specification is meant to test the robustness of the results to using the larger sample of 73 industries, including those with ambiguous state of competition in the 1950s. Column (4) replaces INNUSED1 with INNUSED2, which increases the size of the basic sample by adding several lowinnovation industries. In column (5) I keep INNUSED2 as dependent variable, but I omit the year dummy and interaction terms for 1953 in order to check the robustness of 
the long-run effect of competition to a change in the baseline time period. Finally, in specification (6) $R D 2$ is replaced by $R D 1$, a binary variable equal to 1 for industries with typical $R \& D$-sales ratio over the period higher than $1 \%$ and 0 otherwise. Since the sample of users of innovations is somewhat more heterogeneous with respect to $R \& D$ intensity than the sample of producers, the $1 \%$ cut-off point may also be relevant for classifying these industries according to their R\&D intensity.

\section{Place Table IV approximately here}

It can be seen that the coefficient on CHANGE $\times Y 53$ is not statistically significant in any of these regressions (or when the list of regressors includes only the time effects and the interactions with CHANGE): there is no evidence of different trends in previously collusive and competitive industries before the breakdown of the cartels. Furthermore, the results suggest that innovations used increased following the breakdown of cartels both in the short run and in the long run. With respect to the short run, the coefficients on $C H A N G E \times Y 63$ and $C H A N G E \times Y 68$ are positive and at least one of them is statistically significant at the $5 \%$ level in nearly all specifications except for column (3), where statistical significance is at the $10 \%$ level. The evidence for a long-run effect is even stronger: the coefficients on CHANGE $\times Y 73$ are everywhere positive and statistically significant at the $5 \%$ or $1 \%$ level. Although they vary somewhat in magnitude across specifications, these coefficients collectively suggest a $40-70 \%$ average increase in the number of innovations used in the long run as a result of intensified competition. This is a larger effect than the one implied by the descriptive statistics in Table II, where the average number of innovations used between 
the late 1950s and the early 1970s is constant at 3.3 for industries with a change of competition regime and falls from 4.5 to 3.4 in competitive industries.

One reason for the large estimated effect of competition could be the positive correlation between CHANGE and AGREE. The econometric results from the smaller sample in columns (1)-(2) and (4)-(6) indicate a much larger decline in the use of innovations in the 1960s and early 1970s in industries with high levels of collective bargaining coverage, which is consistent with a view of union power as adversely affecting technological decisions by firms. Note also the large positive coefficients on the year dummies over the same period, despite some variation across specifications. The picture that seems to emerge from Table IV is one of three main determinants of the use of significant innovations in British manufacturing industries. Economic growth, overall technical progress or other economy-wide influences were one positive factor. Another positive factor was the breakdown of cartels as a result of the 1956 Restrictive Trade Practices Act. Finally, strong and increasing union power worked against the use of innovations, and had a stronger impact on the previously collusive industries because these had stronger and more effective unions in the first place. The combined outcome of these mechanisms was little change in the number of innovations used in previously collusive industries and a modest fall in competitive ones. On the other hand, the results from the larger sample in column (3) do not seem to support a significant role for either time effects or union power, although the positive effect of competition on innovations used is still large and statistically significant. As pointed out already, the results from the larger samples that include industries classified as ambiguous with respect to competition must be interpreted with some caution.

Several regressors in the models estimated in Table IV, including the interactions of $R D 1$ or $R D 2$ with the year dummies (not shown), have little or no 
explanatory power. ${ }^{17}$ There is some evidence of a positive effect of $\ln S A L E S$ on the dependent variable, suggesting that growth at the industry level creates incentives for innovation use, although this result is not very robust. Similarly, $\ln P L A N T S I Z E$ has a positive effect on INNUSED in several specifications, suggesting that industries with significant economies of scale (as reflected in larger average plant size) may be more likely to be first users of innovations than other industries.

I checked for evidence of heterogeneity in the effect of competition on the use of innovations but did not find any. I also confirmed that the results are robust to further checks similar to those performed in the previous section, including alternative definitions of CHANGE or the dependent variable, the omission of lnSALES from the model and the inclusion of additional control variables.

\section{CONCLUDING REMARKS}

This paper has examined the impact of price competition on innovation using evidence from a unique natural experiment of policy reform, the introduction of cartel legislation in Britain. The analysis was based on a comparison of industries affected by cartel policy and those not affected. I obtained two main results. First, the intensification of competition following the breakdown of cartels caused a short-run decline in innovations produced, but had no long-run effect. Second, the number of innovations used increased in previously collusive industries in the short run and in the long run.

Admittedly, my analysis is subject to data limitations that could somewhat 'blur' the results. Thus I cannot capture variations in the 'degree of collusion' across industries, since these cannot be determined from the available information. Furthermore, the effects I analyse occurred over a relatively long time period, and it is not easy to entirely rule out confounding factors, although it is not clear what these 
might be. Finally, the SPRU database covers only important innovations, as assessed by industry experts, and the number of those is not large for the average industry, as can be seen in Tables I and II. The production (although not necessarily the use) of important innovations may be largely determined by technology and chance rather than economic factors, unlike incremental innovations or patents. Nevertheless, the difference in the estimated effect of competition on the production and the use of significant innovations in British industry after the abolition of cartels is striking and is unlikely to be due to data limitations. It can also be argued that these are the innovations that matter most from a welfare perspective. Note that the contrast between production and use cannot be driven by process innovations, where producer and user coincide. It must be driven by product innovations, which constitute the large majority in the SPRU database. A test of this suggestion would require distinguishing between types of innovations by merging the samples used in this paper, with a consequent significant loss of observations and detail, and is outside the scope of the present work.

An important methodological difference between the present research and most of the existing literature on innovation relates to the treatment of market structure and profitability. The endogeneity of both these variables has often been neglected or has been dealt with through the use of instrumental variables estimation. A common assumption has been that market power is greater in large firms or in concentrated markets, so to analyse how innovation is affected by market power one may simply examine how it is affected by market share or concentration. This approach does not seem justified once it is recognised that concentration can actually rise as a result of more intense competition (Sutton [1991], Symeonidis [2000a, 2000b, 2002]) or that market structure and innovation are jointly determined variables (Klepper [1996], Sutton [1996, 1998], Symeonidis [1997]). Another approach has been to use a measure 
of performance, such as the price-cost margin, as a proxy for competition. This too could be problematic if the price-cost margin and innovative activity are jointly determined. For instance, profitability may fall in the short run but recover in the longer term following a policy reform that causes price competition to intensify (Symeonidis [2002]). In contrast to these approaches, the underlying theoretical framework in this paper is a view of the competitive process as involving the joint determination of market structure, innovative inputs and outputs, and profitability. The exogenous factors in this framework include demand, technological opportunity and, crucially, the competitive regime facing firms.

My results are in line with the evidence reported by Scherer and Huh [1992], who found a negative effect of competition on R\&D of US firms in the short run but not in the long run; and Geroski [1990], who reports a positive influence of competition on innovations used in 1970s Britain, although he uses very different measures of competition than I do here. ${ }^{18}$ They are also consistent with results from earlier work on the impact of the British cartels on profits and productivity. Swann et al. [1973, 1974] and Symeonidis [2002] have presented evidence of a short-run decline in profitability in industries affected by the 1956 law relative to industries not affected. However, profitability recovered in the longer term in previously collusive industries after their restructuring through exit and merger. It is interesting that the production of innovations changed in a similar way to profitability over time. Previously collusive firms may have cut down on their innovation production activities because of a lack of internal finance caused by the decline in their profits, before resuming their original level of innovation as profits recovered. Furthermore, in Symeonidis [2008] I have described how collusive industries experienced slower productivity growth in the 1950s than after the abolition of cartels, when compared to industries not affected by the 1956 law to control for 
common time trends. It seems that one factor behind the relative rise in productivity growth of previously collusive industries in the 1960s was the positive effect of the more competitive environment on the use of innovations.

The relationship between competition and innovation has been one of the most debated issues in theoretical and empirical microeconomics for the past several decades. The evidence on how the degree of market power across firms or industries affects own R\&D expenditure, innovations produced and patenting activity has been inconclusive or seems at best to point to specific conditions, such as the distance to the technological frontier, that influence the competition-innovation relationship. The findings of this paper suggest a possible shift of emphasis. A robust positive effect of competition on technological progress may exist - but rather than working solely or even primarily through in-house $R \& D$, innovation and patents, it may work largely through an increased propensity of firms facing more competitive conditions to use new technologies, including those that are developed by other firms or industries. 
TABLE I

AVERAGE NUMBER OF INNOVATIONS PRODUCED ACROSS INDUSTRIES

\section{$1952-1956 \quad 1957-1961 \quad 1962-1966 \quad 1967-1971 \quad 1972-1976$}

Industries with

CHANGE = $1(\mathrm{n}=17) \quad 1.8(2.3) \quad 2.9(2.8) \quad 2.4(3.1) \quad 2.1(1.9) \quad 2.2(1.8)$

Industries with

CHANGE $=0(\mathrm{n}=26)$

$3.6(2.8)$

$4.2(4.0)$

$5.3(4.9)$

$6.5(6.7)$

$6.0(6.7)$

All industries $(\mathrm{n}=72)$

$2.6(3.2)$

$3.7(4.5)$

$4.4(5.4)$

$4.8(6.0)$

$4.1(5.1)$

Note: The figures are based on all industries in the data set. Standard deviations in parentheses. $\mathrm{n}$ indicates the number of industries. 
TABLE II

AVERAGE NUMBER OF INNOVATIONS USED ACROSS INDUSTRIES

\section{2-1956 1957-1961 1962-1966 1967-1971 1972-1976}

Industries with

CHANGE = $1(\mathrm{n}=20) \quad 2.5(2.4) \quad 3.3(2.9) \quad 3.9(4.5) \quad 4.0(3.7) \quad 3.3(3.1)$

Industries with

CHANGE = $0(\mathrm{n}=22) \quad 2.6(2.6) \quad 4.5(5.2) \quad 3.9(3.5) \quad 4.3(4.5) \quad 3.4(4.2)$

All industries $(\mathrm{n}=65) \quad 2.8(4.1) \quad 4.2(6.1) \quad 4.3(5.6) \quad 4.6(5.9) \quad 3.9(5.5)$

Note: The figures are based on industries with available data for all variables in all five periods.

Standard deviations in parentheses. $\mathrm{n}$ indicates the number of industries. 
TABLE III: REGRESSION RESULTS FOR INNOVATIONS PRODUCED

\begin{tabular}{|c|c|c|c|c|c|c|}
\hline & (1) & (2) & (3) & (4) & (5) & (6) \\
\hline $\ln S A L E S$ & $\begin{array}{l}0.175 \\
(0.16)\end{array}$ & $\begin{array}{c}-0.013 \\
(0.16)\end{array}$ & $\begin{array}{l}0.030 \\
(0.16)\end{array}$ & $\begin{array}{l}0.224 \\
(0.15)\end{array}$ & $\begin{array}{l}0.026 \\
(0.16)\end{array}$ & $\begin{array}{l}0.091 \\
(0.13)\end{array}$ \\
\hline $\ln (K / L)$ & - & $\begin{array}{l}-0.197 \\
(0.27)\end{array}$ & $\begin{array}{l}-0.074 \\
(0.26)\end{array}$ & - & $\begin{array}{c}-0.223 \\
(0.27)\end{array}$ & $\begin{array}{l}0.142 \\
(0.22)\end{array}$ \\
\hline UNION & - & $\begin{array}{c}-6.57 * * * \\
(2.36)\end{array}$ & $\begin{array}{c}-6.48 * * * \\
(2.35)\end{array}$ & - & $\begin{array}{c}-6.96 * * * \\
(2.46)\end{array}$ & $\begin{array}{c}-3.87 * * \\
(1.72)\end{array}$ \\
\hline Y53 & $\begin{array}{l}-0.028 \\
(0.19)\end{array}$ & $\begin{array}{l}-0.001 \\
(0.20)\end{array}$ & - & $\begin{array}{l}0.092 \\
(0.26)\end{array}$ & $\begin{array}{l}0.083 \\
(0.26)\end{array}$ & $\begin{array}{l}0.080 \\
(0.27)\end{array}$ \\
\hline Y63 & $\begin{array}{l}0.279 \\
(0.19)\end{array}$ & $\begin{array}{c}0.574 * * * \\
(0.22)\end{array}$ & $\begin{array}{c}0.533 * * * \\
(0.21)\end{array}$ & $\begin{array}{l}0.397 \\
(0.24)\end{array}$ & $\begin{array}{c}0.696 * * * \\
(0.26)\end{array}$ & $\begin{array}{c}0.659 * * * \\
(0.25)\end{array}$ \\
\hline Y68 & $\begin{array}{l}0.254 \\
(0.21)\end{array}$ & $\begin{array}{c}0.855 * * * \\
(0.32)\end{array}$ & $\begin{array}{c}0.761^{* *} \\
(0.31)\end{array}$ & $\begin{array}{l}0.338 \\
(0.25)\end{array}$ & $\begin{array}{c}0.906 * * * \\
(0.34)\end{array}$ & $\begin{array}{c}0.748^{* * *} \\
(0.28) 1\end{array}$ \\
\hline Y73 & $\begin{array}{l}0.064 \\
(0.23)\end{array}$ & $\begin{array}{c}1.365^{* *} \\
(0.56)\end{array}$ & $\begin{array}{c}1.218^{* *} \\
(0.54)\end{array}$ & $\begin{array}{l}0.068 \\
(0.27)\end{array}$ & $\begin{array}{c}1.333^{* *} \\
(0.56)\end{array}$ & $\begin{array}{c}0.760^{*} \\
(0.41)\end{array}$ \\
\hline CHANGE $\times Y 53$ & $\begin{array}{l}-0.387 \\
(0.31)\end{array}$ & $\begin{array}{c}-0.411 \\
(0.31)\end{array}$ & - & $\begin{array}{c}-0.618 \\
(0.43)\end{array}$ & $\begin{array}{c}-0.615 \\
(0.44)\end{array}$ & $\begin{array}{c}-0.933 * \\
(0.53)\end{array}$ \\
\hline CHANGE ×Y63 & $\begin{array}{l}-0.458 \\
(0.29)\end{array}$ & $\begin{array}{c}-0.503^{*} \\
(0.29)\end{array}$ & $\begin{array}{c}-0.320 \\
(0.26)\end{array}$ & $\begin{array}{c}-0.402 \\
(0.38)\end{array}$ & $\begin{array}{c}-0.436 \\
(0.38)\end{array}$ & $\begin{array}{c}-0.503 \\
(0.41)\end{array}$ \\
\hline CHANGE $\times$ Y68 & $\begin{array}{c}-0.610^{* *} \\
(0.29)\end{array}$ & $\begin{array}{c}-0.656^{* *} \\
(0.29)\end{array}$ & $\begin{array}{c}-0.469 * \\
(0.27)\end{array}$ & $\begin{array}{c}-0.982 * * \\
(0.41)\end{array}$ & $\begin{array}{c}-0.967 * * \\
(0.41)\end{array}$ & $\begin{array}{c}-0.840^{* *} \\
(0.41)\end{array}$ \\
\hline CHANGE $\times Y 73$ & $\begin{array}{l}-0.424 \\
(0.30)\end{array}$ & $\begin{array}{c}-0.410 \\
(0.31)\end{array}$ & $\begin{array}{l}-0.247 \\
(0.28)\end{array}$ & $\begin{array}{l}-0.416 \\
(0.40)\end{array}$ & $\begin{array}{c}-0.300 \\
(0.41)\end{array}$ & $\begin{array}{l}-0.396 \\
(0.43)\end{array}$ \\
\hline$R D \times C H A N G E \times Y 53$ & - & - & - & $\begin{array}{l}0.310 \\
(0.38)\end{array}$ & $\begin{array}{l}0.289 \\
(0.38)\end{array}$ & $\begin{array}{l}0.506 \\
(0.43)\end{array}$ \\
\hline$R D \times C H A N G E \times Y 63$ & - & - & - & $\begin{array}{c}-0.129 \\
(0.37)\end{array}$ & $\begin{array}{c}-0.138 \\
(0.37)\end{array}$ & $\begin{array}{l}0.107 \\
(0.36)\end{array}$ \\
\hline$R D \times C H A N G E \times Y 68$ & - & - & - & $\begin{array}{l}0.453 \\
(0.34)\end{array}$ & $\begin{array}{l}0.382 \\
(0.34)\end{array}$ & $\begin{array}{l}0.411 \\
(0.34)\end{array}$ \\
\hline$R D \times C H A N G E \times Y 73$ & - & - & - & $\begin{array}{c}-0.003 \\
(0.35)\end{array}$ & $\begin{array}{c}-0.160 \\
(0.36)\end{array}$ & $\begin{array}{l}-0.047 \\
(0.37)\end{array}$ \\
\hline $\begin{array}{l}\text { Interactions of } R D \\
\text { with year dummies }\end{array}$ & Yes & Yes & Yes & Yes & Yes & Yes \\
\hline Log Likelihood & -295.7 & -292.0 & -293.7 & -293.5 & -289.5 & -474.7 \\
\hline No. of industries & 43 & 43 & 43 & 43 & 43 & 72 \\
\hline No. of observations & 215 & 215 & 215 & 215 & 215 & 360 \\
\hline
\end{tabular}

Note: $R D$ denotes $R D 2$ in columns $1-3$ and $R D 12$ in columns 4-6. In column 6 CHANGE2 replaces CHANGE. Standard errors in parentheses; *, **, *** indicate significance at $10 \%, 5 \%$ and $1 \%$ level respectively. 
TABLE IV: REGRESSION RESULTS FOR INNOVATIONS USED

\begin{tabular}{|c|c|c|c|c|c|c|}
\hline & \multicolumn{3}{|c|}{ Dep. Variable: INNUSED1 } & \multicolumn{3}{|c|}{ Dep. Variable: INNUSED2 } \\
\hline & $(1)$ & $(2)$ & (3) & $(4)$ & (5) & (6) \\
\hline $\ln S A L E S$ & $\begin{array}{l}0.474 * * * \\
(0.16)\end{array}$ & $\begin{array}{c}0.457 * * \\
(0.18)\end{array}$ & $\begin{array}{l}0.186 \\
(0.15)\end{array}$ & $\begin{array}{l}0.173 \\
(0.12)\end{array}$ & $\begin{array}{l}0.109 \\
(0.12)\end{array}$ & $\begin{array}{l}0.091 \\
(0.12)\end{array}$ \\
\hline $\ln (K / L)$ & - & $\begin{array}{l}0.460 \\
(0.29)\end{array}$ & $\begin{array}{l}0.252 \\
(0.19)\end{array}$ & - & $\begin{array}{l}0.317^{*} \\
(0.16)\end{array}$ & $\begin{array}{l}0.094 \\
(0.16)\end{array}$ \\
\hline $\ln P L A N T S I Z E$ & - & $\begin{array}{l}0.590 \\
(0.41)\end{array}$ & $\begin{array}{c}1.110^{* * *} \\
(0.33)\end{array}$ & - & $\begin{array}{c}0.666 * * * \\
(0.23)\end{array}$ & $\begin{array}{c}0.504^{* *} \\
(0.23)\end{array}$ \\
\hline Y53 & $\begin{array}{l}-0.056 \\
(1.33)\end{array}$ & $\begin{array}{c}-0.044 \\
(1.31)\end{array}$ & $\begin{array}{c}-1.178 \\
(1.07)\end{array}$ & $\begin{array}{l}-0.494 \\
(0.93)\end{array}$ & - & $\begin{array}{l}-0.071 \\
(0.85)\end{array}$ \\
\hline Y63 & $\begin{array}{c}2.607^{* *} \\
(1.09)\end{array}$ & $\begin{array}{c}2.408^{* *} \\
(1.09)\end{array}$ & $\begin{array}{l}0.931 \\
(0.90)\end{array}$ & $\begin{array}{l}-0.088 \\
(0.88)\end{array}$ & $\begin{array}{l}-0.234 \\
(0.82)\end{array}$ & $\begin{array}{l}-0.327 \\
(0.77)\end{array}$ \\
\hline Y68 & $\begin{array}{l}1.294 \\
(1.10)\end{array}$ & $\begin{array}{l}0.972 \\
(1.09)\end{array}$ & $\begin{array}{l}0.248 \\
(0.91)\end{array}$ & $\begin{array}{c}2.465^{* * *} \\
(0.76)\end{array}$ & $\begin{array}{l}1.925 * * * \\
(0.73)\end{array}$ & $\begin{array}{c}1.969 * * * \\
(0.73)\end{array}$ \\
\hline$Y 73$ & $\begin{array}{l}1.969 \\
(1.21)\end{array}$ & $\begin{array}{l}1.461 \\
(1.24)\end{array}$ & $\begin{array}{l}-1.102 \\
(1.09)\end{array}$ & $\begin{array}{c}3.139 * * * \\
(0.80)\end{array}$ & $\begin{array}{c}2.375^{* * *} \\
(0.80)\end{array}$ & $\begin{array}{c}2.471^{* * *} \\
(0.79)\end{array}$ \\
\hline$A G R E E \times Y 53$ & $\begin{array}{c}-0.711 \\
(1.73)\end{array}$ & $\begin{array}{l}-0.664 \\
(1.72)\end{array}$ & $\begin{array}{l}1.010 \\
(1.31)\end{array}$ & $\begin{array}{l}-0.225 \\
(1.18)\end{array}$ & - & $\begin{array}{l}-0.787 \\
(1.12)\end{array}$ \\
\hline$A G R E E \times Y 63$ & $\begin{array}{c}-3.681^{* * * *} \\
(1.42)\end{array}$ & $\begin{array}{c}-3.580 * * \\
(1.42)\end{array}$ & $\begin{array}{c}-1.469 \\
(1.10)\end{array}$ & $\begin{array}{l}0.018 \\
(1.07)\end{array}$ & $\begin{array}{l}0.287 \\
(1.04)\end{array}$ & $\begin{array}{l}0.089 \\
(1.01)\end{array}$ \\
\hline$A G R E E \times Y 68$ & $\begin{array}{c}-2.007 \\
(1.41)\end{array}$ & $\begin{array}{c}-1.985 \\
(1.41)\end{array}$ & $\begin{array}{l}-0.727 \\
(1.09)\end{array}$ & $\begin{array}{c}-3.030 * * * \\
(0.96)\end{array}$ & $\begin{array}{c}-2.404 * * * \\
(0.91)\end{array}$ & $\begin{array}{c}-2.461 * * * \\
(0.93)\end{array}$ \\
\hline$A G R E E \times Y 73$ & $\begin{array}{c}-3.891^{* *} \\
(1.58)\end{array}$ & $\begin{array}{c}-3.863^{* *} \\
(1.60)\end{array}$ & $\begin{array}{l}0.091 \\
(1.25)\end{array}$ & $\begin{array}{c}-4.181^{* * *} \\
(1.01)\end{array}$ & $\begin{array}{c}-3.459 * * * \\
(0.98)\end{array}$ & $\begin{array}{c}-3.249 * * * \\
(0.99)\end{array}$ \\
\hline CHANGE $\times Y 53$ & $\begin{array}{l}0.353 \\
(0.36)\end{array}$ & $\begin{array}{l}0.360 \\
(0.36)\end{array}$ & $\begin{array}{l}0.118 \\
(0.35)\end{array}$ & $\begin{array}{l}0.158 \\
(0.22)\end{array}$ & - & $\begin{array}{l}0.191 \\
(0.21)\end{array}$ \\
\hline CHANGE $\times$ Y63 & $\begin{array}{c}0.688^{* *} \\
(0.30)\end{array}$ & $\begin{array}{c}0.735^{* *} \\
(0.30)\end{array}$ & $\begin{array}{l}0.508^{*} \\
(0.29)\end{array}$ & $\begin{array}{l}0.032 \\
(0.20)\end{array}$ & $\begin{array}{l}0.050 \\
(0.25)\end{array}$ & $\begin{array}{l}0.168 \\
(0.19)\end{array}$ \\
\hline CHANGE $\times Y 68$ & $\begin{array}{l}0.458 \\
(0.29)\end{array}$ & $\begin{array}{l}0.560^{*} \\
(0.30)\end{array}$ & $\begin{array}{l}0.400 \\
(0.29)\end{array}$ & $\begin{array}{c}0.426 * * \\
(0.18)\end{array}$ & $\begin{array}{c}0.439 * * \\
(0.18)\end{array}$ & $\begin{array}{c}0.445^{* *} \\
(0.18)\end{array}$ \\
\hline CHANGE $\times Y 73$ & $\begin{array}{c}1.135^{* * *} \\
(0.34)\end{array}$ & $\begin{array}{l}1.224 * * * \\
(0.35)\end{array}$ & $\begin{array}{c}0.801^{* *} \\
(0.31)\end{array}$ & $\begin{array}{c}0.642 * * * \\
(0.20)\end{array}$ & $\begin{array}{c}0.633^{* * *} \\
(0.20)\end{array}$ & $\begin{array}{l}0.542 * * * \\
(0.19)\end{array}$ \\
\hline $\begin{array}{l}\text { Interactions of } R D \\
\text { with year dummies }\end{array}$ & Yes & Yes & Yes & Yes & Yes & Yes \\
\hline Log Likelihood & -300.6 & -298.2 & -474.2 & -494.3 & -503.6 & -483.2 \\
\hline No. of industries & 47 & 47 & 73 & 58 & 58 & 58 \\
\hline No. of observations & 230 & 230 & 357 & 285 & 285 & 285 \\
\hline
\end{tabular}

Note: $R D$ denotes $R D 2$, except in column 6 where it denotes $R D 1$. In column 3 CHANGE2 replaces CHANGE. Standard errors in parentheses; *, **, *** indicate significance at $10 \%, 5 \%$ and $1 \%$ level respectively. 


\section{DATA APPENDIX}

The data sources on competition and innovation were described in the text. Sales revenue data at current net producer prices were obtained from the industry reports of the Census of Production (various years) and from Business Monitors. Industry-specific price indices were obtained from the Annual Abstract of Statistics or computed from Census of Production data on volume of sales reported together with sales revenue. Estimates of capital stock, defined as plant and machinery, were taken from O'Mahoney and Oulton [1990]. Data on employment and plant numbers were taken from the relevant Summary Tables and from individual industry reports of the Census of Production. Sales revenue, capital stock and employment data for 1953 are not available, but I have constructed estimates on the assumption that the 1953-1954 growth rate was equal to the annual growth rate between 1954 and 1958.

The percentages of employees across three-digit industries covered by collective agreements in 1973 come from the New Earnings Survey of that year. Data on union density at a level of aggregation between the two-digit and the three-digit were taken from Bain and Price [1980]. The advertising data were obtained from various issues of the Statistical Review of Press and TV Advertising.

Finally, R\&D expenditure data for the UK are available for various years since 1964 at a level of aggregation between the two-digit and the three-digit (the 'sub-sector' level). They have been published in Research and Development Expenditure, Studies in Official Statistics no. 21, HMSO, 1973; Research and Development: Expenditure and Employment, Studies in Official Statistics no. 27, HMSO, 1976; and Industrial Research and Development Expenditure and Employment, Business Monitor MO14 (various years). To derive R\&D-sales ratios for three-digit industries, the UK data were used to determine 
R\&D intensities (measured as the ratio of company-funded R\&D to sales) at the sub-sector level and, in addition, US data were used as a guide for relative R\&D intensities of industries within any UK sub-sector. R\&D expenditure data for the US, at a level of aggregation between the three-digit and the four-digit, have been published by the Federal Trade Commission in the Annual Line of Business reports from 1973 to 1977. 


\section{REFERENCES}

Acs, Z. J. and Audretsch, D. B., 1988, 'Innovation in Large and Small Firms: An Empirical Analysis,' American Economic Review, 78, pp. 678-690.

Aghion, P., Bloom, N., Blundell, R., Griffith, R. and Howitt P., 2005, 'Competition and Innovation: An Inverted U Relationship,' Quarterly Journal of Economics, 120, pp. 701-728.

Aghion, P., Blundell, R., Griffith, R., Howitt P. and Prantl, S., 2009 'The Effects of Entry on Incumbent Innovation and Productivity,' Review of Economics and Statistics, 91, pp. 20-32.

Amiti, M. and Khandelwal, A., 2013, 'Import Competition and Quality Upgrading,' Review of Economics and Statistics, 95, pp. 476-490.

Arora, A., Cohen W. M. and Walsh, J. P., 2016, 'The Acquisition and Commercialization of Invention in American Manufacturing: Incidence and Impact,' Research Policy, 45, pp. 1113-1128.

Autor, D., Dorn, D., Hanson, G. H., Pisano, G. and Shu, P., 2016, ‘Foreign Competition and Domestic Innovation: Evidence from U.S. Patents,' CEPR Discussion Paper 11664.

Bain, G. S. and Price, R., 1980, Profiles of Union Growth (Basil Blackwell, Oxford).

Beneito, P., Coscollá-Girona, P., Rochina-Barrachina M. E. and Sanchis, A., 2015, 'Competitive Pressure and Innovation at the Firm Level,' Journal of Industrial Economics, 63, pp. 422-457.

Bloom, N., Draca, M. and Van Reenen, J., 2016, 'Trade Induced Technical Change? The Impact of Chinese Imports on Innovation, IT and Productivity,' Review of Economic Studies, 83, pp. 87-117. 
Blundell, R., Griffith, R. and Van Reenen J., 1995, 'Dynamic Count Data Models of Technological Innovation,’ Economic Journal, 105, pp. 333-344.

Blundell, R., Griffith, R. and Van Reenen J., 1999, 'Market Share, Market Value and Innovation in a Panel of British Manufacturing Firms,' Review of Economic Studies, 66, pp. 529-554.

Broadberry, S. and Crafts, N., 2001, 'Competition and Innovation in 1950's Britain,' Business History, 43, pp. 97-118.

Burn, D. (ed.), 1958, The Structure of British Industry, 2 volumes

Cameron, A. C. and Trivedi, P. K., 1998, Regression Analysis of Count Data, (Cambridge University Press, Cambridge).

Cohen, W., 1995, 'Empirical Studies of Innovative Activity,' in Stoneman, P. (ed.), Handbook of the Economics of Innovation and Technological Change (Blackwell, Oxford).

Cohen, W. M. and Levinthal, D. A., 1989, 'Innovation and Learning: The Two Faces of R\&D,’ Economic Journal, 99, pp. 569-596.

Correa, J. A., 2012, 'Innovation and Competition: An Unstable Relationship,' Journal of Applied Econometrics, 27, pp. 160-166.

Geroski, P. A., 1990, 'Innovation, Technological Opportunity, and Market Structure,' Oxford Economic Papers, 42, pp. 586-602.

Geroski, P. A., 1994, Market Structure, Corporate Performance and Innovative Activity (Clarendon Press, Oxford).

Gilbert, R. 2006, 'Looking for Mr. Schumpeter: Where Are we in the CompetitionInnovation Debate?' in Jaffe, A. B., Lerner, J. and Stern, S. (eds.), Innovation Policy and the Economy, Vol. 6. (M.I.T. Press, Cambridge, MA). 
Gorodnichenko, Y., Svejnar, J. and Terrell, K., 2010, 'Globalization and Innovation in Emerging Markets,' American Economic Journal: Macroeconomics, 2, pp. 194226.

Griffith, R., Harrison, R. and Simpson, H., 2010, 'Product Market Reform and Innovation in the EU,' Scandinavian Journal of Economics, 112, pp. 389-415.

Griffith, R., Redding, S. and Van Reenen, J., 2004, 'Mapping the Two Faces of R\&D: Productivity Growth in a Panel of OECD Industries,' Review of Economics and Statistics, 86, pp. 883-895.

Hart, P. E., Utton M. A. and Walshe, G., 1973, Mergers and Concentration in British Industry (Cambridge University Press, Cambridge).

Hashmi, A. R., 2013, 'Competition and Innovation: The Inverted-U Relationship Revisited,' Review of Economics and Statistics, 95, pp. 1653-1668.

Hausman, J., Hall, B. H. and Griliches, Z., 1984, 'Econometric Models for Count Data with an Application to the Patents-R\&D Relationship,' Econometrica, 52, pp. 909-938.

Heath, J. B., 1961, 'Restrictive Practices and After,' Manchester School of Economic and Social Studies, 29, pp. 173-202.

Heath, J., 1963, Still Not Enough Competition? Business Restrictive Practices Reexamined, 2nd edition (Institute of Economic Affairs, London).

Kitchin, P. D., 1976, 'Effective Rates of Protection for United Kingdom Manufacturing in 1963 and 1968,' in Artis, M. J. and Nobay, A. R. (eds.), Essays in Economic Analysis (Cambridge University Press, Cambridge).

Klepper, S., 1996, 'Entry, Exit, Growth, and Innovation over the Product Life Cycle,' American Economic Review, 86, pp. 562-583. 
Liu, X., Hodgkinson, I. R. and Chuang, F-M., 2014, 'Foreign Competition, Domestic Knowledge Base and Innovation Activities: Evidence from Chinese High-tech Industries, Research Policy, 43, pp. 414-422.

Mansfield, E., Rapoport, J., Schnee, J., Wagner, S. and Hamburger, M., 1971, Research and Innovation in the Modern Corporation (MacMillan, London).

Nicholas, T., 2003, 'Why Schumpeter Was Right: Innovation, Market Power, and Creative Destruction in 1920s America,' Journal of Economic History, 63, pp. 1023-1058.

O'Mahony, M. and Oulton, N., 1990, 'Industry-level Estimates of the Capital Stock in UK Manufacturing, 1948-85,’ NIESR Discussion Paper no. 172.

Pakes, A. and Schankerman, M., 1984, 'The Rate of Obsolescence of Patents, Research Gestation Lags, and the Private Returns to Research Resources,' in Griliches, Z. (ed.), R\&D, Patents, and Productivity (University of Chicago Press, Chicago).

Political and Economic Planning, 1957, Industrial Trade Associations (George Allen \& Unwin, London).

Robson, M., Townsend, J. and Pavitt, K., 1988, 'Sectoral Patterns of Production and Use of Innovations in the UK: 1945-1983,' Research Policy, 17, pp. 1-14.

Scherer, F. M., 1967, 'Market Structure and the Employment of Scientists and Engineers,' American Economic Review, 57, pp. 524-531.

Scherer, F. M. and Huh, K., 1992, 'R\&D Reactions to High-technology Import Competition,' Review of Economics and Statistics, 74, pp. 202-212.

Schmookler, J., 1966, Invention and Economic Growth (Harvard University Press, Cambridge, MA).

Schott, K., 1976, 'Investment in Private Industrial Research and Development in Britain,' Journal of Industrial Economics, 25, pp. 81-99. 
Sutton, J., 1991, Sunk Costs and Market Structure (M.I.T. Press, Cambridge, MA).

Sutton, J., 1996, 'Technology and Market Structure,' European Economic Review, 40, pp. 511-530.

Sutton, J., 1998, Technology and Market Structure (M.I.T. Press, Cambridge, MA).

Swann, D., O'Brien, D. P., Maunder, W. P. J. and Howe, W. S., 1973, Competition in British Industry: Case Studies of the Effects of Restrictive Practices Legislation, Department of Economics, Loughborough University of Technology.

Swann, D., O'Brien, D. P., Maunder, W. P. J. and Howe, W. S., 1974, Competition in British Industry (George Allen \& Unwin, London).

Symeonidis, G., 1997, 'Innovation, Firm Size and Market Structure: Schumpeterian Hypotheses and Some New Themes,' OECD Economic Studies, 27, pp. 35-70.

Symeonidis, G., 2000a, 'Price Competition and Market Structure: The Impact of Cartel Policy on Concentration in the UK,' Journal of Industrial Economics, 48, pp. 126.

Symeonidis, G., 2000b, Price Competition, Non-price Competition, and Market Structure: Theory and Evidence,' Economica, 67, pp. 437-456.

Symeonidis, G., 2002, The Effects of Competition (M.I.T. Press, Cambridge, MA).

Symeonidis, G., 2007, 'Price Competition, Innovation and Profitability: Theory and UK Evidence,' in Levenstein, M. C. and Salant, S. W. (eds.), Cartels (Edward Elgar, Cheltenham).

Symeonidis, G., 2008, 'The Effect of Competition on Wages and Productivity: Evidence from the UK,' Review of Economics and Statistics, 90, pp. 134-146.

Townsend, J., Henwood, F., Thomas, G., Pavitt, K. and Wyatt, S., 1981, 'Science and Technology Indicators for the UK: Innovations in Britain since 1945,' SPRU Occasional Paper Series no. 16. 
Vives, X., 2008, 'Innovation and Competitive Pressure,' Journal of Industrial Economics, 56, pp. 419-469.

Von Hippel, E., 1988, The Sources of Innovation (Oxford University Press, Oxford). 
${ }^{1}$ Another approach that also avoids standard measures of competition and emphasises fundamentals of competitive pressure following Vives [2008] is applied by Beneito et al. [2015]. They find that greater product substitutability and higher costs of entry lead to more process innovation but less product innovation, whereas market enlargement spurs both product and process innovation.

${ }^{2}$ There is, however, a small empirical literature on the determinants of firms' decisions to produce new technology internally or acquire it from outside sources. Liu et al. [2014] have found a negative effect of import intensity on internal R\&D expenditure and a positive one on the purchase of technology from external sources across Chinese industries. Although this 'make or buy' decision is not the same as my distinction between production and use of innovations, my results similarly indicate that competition affects these two dimensions of innovative activity in different ways.

${ }^{3}$ More than half of the industries classified as collusive had agreements covering all or nearly all industry products and most of the others had agreements covering more than $70 \%$ of total industry sales. Furthermore, more than half of the industries classified as competitive were free from any significant restrictive agreements and most of the others had agreements covering less than $10 \%$ of total industry sales. The use of a continuous competition measure instead of cut-off points has proved impractical for a variety of reasons (see Symeonidis [2002]). Industries with significant government participation or intervention for part or all of the period under study (sugar, steel, aircraft, locomotives) were excluded.

4 These were mainly industries where the products subject to significant restrictions accounted for $20 \%$ to $50 \%$ of total industry sales or where the restrictions had an uncertain effect of competition and covered more than $20 \%$ of industry sales. Treating 
this group of industries as an intermediate category is justified by their characteristics. Collusive industries in the 1950s had, on average, higher capital intensity, larger average plant size, lower advertising intensity and lower R\&D-intensity than competitive industries. For all of these variables, the group of ambiguous industries had means that were between the collusive and the competitive ones.

5 The three-digit (or 'minimum list heading') level of aggregation defines a total of about 130 manufacturing industries and has been widely used in studies with British data on innovation (for instance, Geroski [1990, 1994]) or productivity growth (Symeonidis [2008]). To prevent sporadic innovative activity from increasing the noise in the data, I have not included in my samples a small number of industries with fewer than three innovations produced or used, respectively, during the 25-year period under study.

${ }^{6}$ For innovations produced (but not for innovations used) I have also excluded innovations by public research establishments or industrial research associations, and those reported as having originated outside the UK. Note that any attempt to count the number of significant innovations is subject to possible biases in the evaluation procedure. Fortunately, in the case of the SPRU database any such biases seem to affect the comparability of innovative activity across industries rather than the comparability over time for any given industry. This is not a problem for my analysis because I use panel data, so time-invariant differences across industries in the measurement of the dependent variable become part of the industry-specific effects and do not affect the coefficients of interest. Significant inconsistencies over time appear in very few industries: there is over-representation of the 1970s in two high-innovation industries, textile machinery and scientific and industrial instruments (Townsend et al. [1981]). This may be due to the fact that the data were collected in waves, and the same experts 
were not necessarily contacted in each wave. These industries were excluded from my samples.

${ }^{7}$ The assumption of a one-year lag has also been used in previous studies using the SPRU data, such as Blundell et al. [1995]. Although a two-year lag may be more in line with evidence from large British firms (Schott [1976]), a large fraction of the innovators in the SPRU database are small firms, whose $R \& D$ projects tend to be less expensive and smaller in scope than those of large firms. In any case, I will check the robustness of my results to the use of a two-year lag.

8 These time periods have the additional benefit of minimising the effect of any inaccuracies caused by the use of focal-point dates (1955, 1960, 1965 and so on) by experts unsure of the precise date of introduction of an innovation.

${ }^{9}$ The rate of growth has sometimes been used instead of market size as a regressor in empirical studies of innovation. I have also estimated a model including the lagged growth in sales revenue. The results were similar to those presented below.

${ }^{10}$ In my earlier work (Symeonidis [2007, 2002], I used 1951-55 as the baseline period in this regression. As a result, I was not able to identify any short-run effects of competition on innovations produced. Other differences with my earlier work include the use of a larger sample and more control variables, and robustness checks that involve several alternative specifications.

11 A potential objection to my choice of baseline time period might be that if the breakdown of collusion in an industry had been anticipated after 1956, innovation activity could have been driven not by the old regime but by the anticipation of the new. This is unlikely to be the case, however, because, as described in section II, there was significant uncertainty for several years after 1956 about the attitude of the Restrictive Practices Court, and this continued to some extent even after the first 
agreements were struck down in 1959. In fact, many industries chose to defend their agreements in Court, some as late as the mid-1960s, and several even managed to have their agreements upheld.

12 The interaction terms with $R D 2$ are not endogenous: whether the typical R\&D-sales ratio in an industry is higher or lower than $2 \%$ is largely determined by exogenous characteristics, such as technological opportunity. Of course, whether the R\&D-sales ratio is $4 \%$ or $5 \%$, say, may be to some extent determined endogenously. But my binary variable $R D 2$ is not very sensitive to endogenous factors that affect $R \& D$ intensity. The assumption of exogeneity of $R D 2$ is also consistent with the fact that a comparison of R\&D-sales ratios across various years revealed few instances where an industry had moved from below $2 \%$ to above $2 \%$ or vice versa. The use of a binary variable for $R \& D$ intensity not only mitigates the potential endogeneity problem, but was also necessary in light of the lack of information on precise $R \& D$-sales ratios for several industries, even though these industries could be easily classified using a cut-off point.

${ }^{13}$ Although union power might be influenced by the competitive environment, this applies much less to union density. For instance, whereas the monetary benefits from union membership may decrease if a union's bargaining power in wage negotiations declines following an intensification of competition, many workers may also think that being union members could reduce their chances of being laid off. Union density is essentially seen here as a variable that picks up primarily exogenous influences on union power.

${ }^{14}$ I have, however, verified that including the logarithm of the number of firms (the best available measure of market structure for the industry categories in my sample) as an explanatory variable does not affect the results. The coefficient on that 
variable (whether included on its own or together with its squared value) was not statistically significant.

15 A regression that includes only time effects and interactions with CHANGE but excludes all other explanatory variables gives very similar results. Note that the coefficient on $C H A N G E \times Y 53$ has the same sign as that on $C H A N G E \times Y 63$ : even if different trends existed and are imprecisely estimated, they were, if anything, reversed in the 1960s. One interpretation of this potential reversal would be that the negative short-run effect of the breakdown of cartels is underestimated in my model. Under an alternative interpretation, any pre-treatment differences in the evolution of INNOV could reflect random fluctuations unrelated to collusion. One would therefore still conclude that the evolution of innovations produced after the breakdown of cartels was not driven by pre-existing trends across industries.

${ }^{16}$ The year 1973 is the first for which data on collective bargaining arrangements at the three-digit industry level are available. The implicit assumption here is that, although the percentage of the workforce covered must have changed over time in any given industry, inter-industry differences in coverage did not change much during this period and were primarily determined by exogenous industry characteristics. An advantage of using 1973 figures is that AGREE is definitely exogenous with respect to CHANGE. In preliminary regressions I also included the variable UNION, as previously defined. Unlike data on collective bargaining coverage, union density data are available for the whole period under study, albeit only at a level of aggregation between the two-digit and the three-digit. UNION was not statistically significant.

17 Two other variables with little explanatory power are the number of firms and the sales growth rate. A third variable, lagged labour productivity growth, has a consistently negative and sometimes statistically significant effect on the use of innovations. The 
estimated competition effect is slightly larger in specifications including labour productivity growth, although this is probably due to the omission of the first time period of the panel in those regressions.

${ }^{18}$ Whereas in most of the previous literature the broad question is about the effect of market power on innovation, this paper focuses on cartels. Is there any reason to think that cartels might approach innovation differently than other firms that face little price competition? It is difficult to give a conclusive answer to this question, but two relevant observations can be made. The theoretical literature on the links between collusion and innovation is inconclusive, just as the more mainstream Schumpeterian literature, so there is no clear theoretical reason to expect that my results are driven by the particular way competition is measured in this paper. Furthermore, as I mentioned in section II, the British cartels did not regulate $R \& D$ expenditures by individual firms, and this also suggests there may be no important differences between the British cartel firms and other firms that face little price competition in the way they approach innovation. 